\title{
Has the adoption of CSR initiatives by MNCs improved the situation in Nigeria's Niger Delta region?'
}

\author{
Ijeoma Ogechi Nwachukwu \\ Port Harcourt \\ Nigeria.
}

\begin{abstract}
This paper aims to highlight the negative effects the host communities in the Niger Delta have experienced due to oil and gas activities since the discovery and production of crude oil on their lands over 30 years ago. The objective of this paper is to show the amount of crude oil that has been spilled either through operational activities or by poor maintenance of equipment owned by the organizations and perception of the individuals and communities affected. Findings of the study indicate strategies that the multinational companies (MNCs) and the government may use to prevent disharmony and distrust between themselves and host communities. It also showedthe importance of corporate social responsibility (CSR)in not only improving the brand name but also giving back to the environment where they operate. Finally, the paper concludes by discussing the limitations and recommendations of the research and how they may be addressed with further research.
\end{abstract}

Keywords: Corporate social responsibility, multinational companies, host communities, Niger Delta, Stakeholders

\section{Introduction}

Historically, crude oil in its commercial quantity was first discovered in Nigeria in 1956, before this time, the nation largely depended on agriculture and exportation of its products (Odularu, 2007). He added that due to this discovery, Nigeria turned its focus to this sector so that by the year 2000, about $98 \%$ of its earnings are mostly from the exportation of crude oil and gas. The affected area- the Niger Delta is part of Nigeria's coastal area covering about $20,000 \mathrm{~km} 2$ and housing about 20 million people from different ethnic groups. The Niger Delta states are made up of nine states, Ondo, Edo, Delta, Rivers, Bayelsa, Imo, Abia, Akwa Ibom, and Cross River. This area has many ethnic groups with several languages and a population of about 40million people which is almost a quarter of the total population (Odoemene, 2014). Balonga (2009) and Nyananyo (2007) as cited by Odoemene (2014) stated that the region has one of the highest population densities globally, with 265 people in every square kilometer.

Figure 1: Maps of Nigeria and Niger Delta states

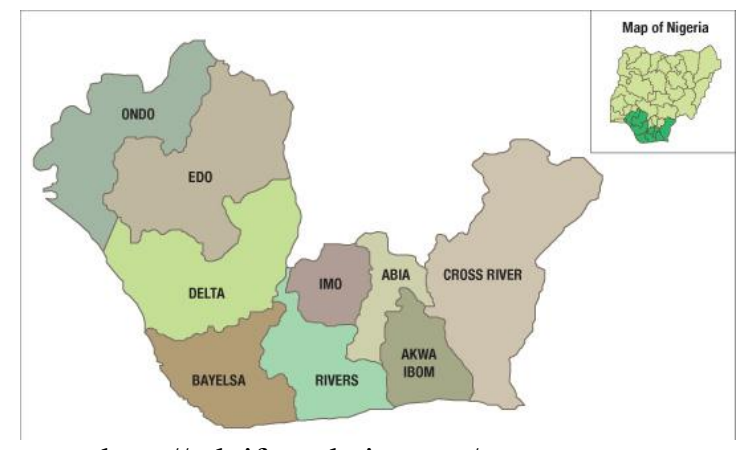

Source: http://ndpifoundation.org/

The Niger Delta consists of $7.5 \%$ of Nigeria's total land area and it holds over $90 \%$ of the nation's crude oil and gas reserves however it has the biggest unequal economic situation in the country (stakeholdersdemocracy.org, n.d). It added that social amenities are less than the national average with poor living conditions. After oil was first discovered by Shell in Oloibiri in 1956, other oil companies followed such as Chevron in 1963 in Escravos Bay, Elf in 1962 at Obagi and Agip and Texaco in 1962 and 1970 respectively (Ering et al., 2013). They added that many of the community leaders have led the fight for the people's rights against the oil companies such as Jasper Isaac Boro and the late Ken Saro Wiwa and yet not much has changed since then. There are two major causes of oil spill, firstly as a result of corrosion and lack of maintenance of the oil companies equipment and secondly, as a result of sabotage. 
Nwilo and Badejo (2008) noted that about $50 \%$ is caused by corrosion of pipeline and equipment, $28 \%$ caused by sabotage and $21 \%$ caused by oil production activities. They added that the remaining $1 \%$ is caused by other engineering actions. The Nigerian government has a joint venture with all the oil MNCs operating within its region through its national company NNPC. Iyayi (2000) as cited by Inoni et al. (2006) showed these details in the table below.

Figure 2: Major Oil Companies operating in the Niger Delta

\subsection{Aim}

\begin{tabular}{|l|l|l|l|l|}
\hline No & Oil Company & Shareholders & Operators & $\begin{array}{l}\text { Share of National } \\
\text { Production }\end{array}$ \\
\hline 1 & $\begin{array}{l}\text { Shell Petroleum } \\
\text { Development (SPDC) }\end{array}$ & $\begin{array}{l}\text { NNPC }-55 \% \\
\text { Shell }-30 \% \\
\text { Elf }-10 \% \\
\text { Agip }-5 \%\end{array}$ & Shell & $42.0 \%$ \\
\hline 2 & Mobil Producing Nigeria & $\begin{array}{l}\text { NNPC }-50 \% \\
\text { Mobil }-42 \%\end{array}$ & Mobil & $21.0 \%$ \\
\hline 3 & Chevron Nigeria & $\begin{array}{l}\text { NNPC }-60 \% \\
\text { Chevron }-40 \%\end{array}$ & Chevron & $19.0 \%$ \\
\hline 4 & Nigeria Agip Oil & $\begin{array}{l}\text { NNPC }-60 \% \\
\text { Agip }-40 \%\end{array}$ & Agip & $7.5 \%$ \\
\hline 5 & Elf Petroleum Nigeria & $\begin{array}{l}\text { NNPC }-60 \% \\
\text { Elf-40\% }\end{array}$ & Elf & $2.6 \%$ \\
\hline 6 & $\begin{array}{l}\text { Texaco } \\
\text { (Nigeria) Petroleum }\end{array}$ & $\begin{array}{l}\text { NNPC }-60 \% \\
\text { Cexaco-20\% } \\
\text { Chevron-20\% }\end{array}$ & Texaco & $1.7 \%$ \\
\hline
\end{tabular}

Source: Iyayi (2000)

The global business environment has become one where an organization's actions can now be viewed globally, which could affect its prospects if viewed in a negative light. The effect of a company's' actions and operations are now closely viewed so as not to have adverse effects on the environment and its people. They have come to realize that mitigated or reparative actions are necessary on their parts especially as the needs of the people affected changes constantly as does the environment also. Companies now implement CSR initiatives to balance out their activities as time has shown that only profit/money making ventures will not be successful but through effective and sustained initiatives their businesses have a longer span of life.

Host communities on land and swamp areas have had their livelihood damaged and the poverty and mortality rates increased over the years. The MNCs and a privileged few have been the major stakeholders that have benefitted from these activities. This paper hopes to show through information gathered the amount of crude oil that has been spilled either through operational activities or those caused by poor maintenance of equipment owned by the organizations. Nwilo and Badejo (2005) noted that after crude oil was discovered in Nigeria, the country has endured the negative impact of the consequences of pollution of its environment. They added that due to the continuous growth of oil production and poor maintenance of environmental standards, this area has suffered greatly. Egbe and Thompson (2010) listed out the areas affected by pollution to include water bodies (fresh and saltwater), soil, plants, human health and economy of the region. Other reports on this issue have dealt mainly on dealing with the effects of pollution, however, the author focuses on preventive measures and what these companies, the government can do to prevent the issue even before it occurs. This research investigated the perception of individuals in communities in the Niger Delta in Nigeria affected by years of operations of MNCs of the Oil and Gas sectors and observed if it had changed over the years. Previously these companies were mainly focused on maximizing profits, in recent times, they have come to realize the importance of CSR initiatives and benefits. This research is to assess if these have had any impact on these companies' efforts at helping the communities or if they think that they can do a lot more.

\section{Figure 3: Occupation of Niger Delta population}

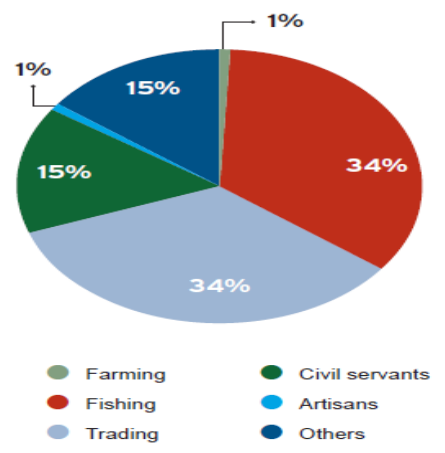

Source: PIND foundation, 2014 
The pie chart above shows the various occupations prominent in the Niger Delta areas, there is a tie between fishing and trading with both at $34 \%$ of the population. This is so because these occupations complement each other as the products from the fishermen and are sold by the traders. There is also a tie of $15 \%$ with both Civil servants and other professions. Lastly, farmers and artisans make up $2 \%$ of the population also. The primary professions in the Niger Delta used to be farming and fishing, secondary professions included distillation of alcohol, textile weaving and construction of boats (Steppingstones.org, 2014). It added that others included transportation and trading.

The pie chart above would have been the ideal statistics several years ago before the advent of oil exploration and production in the Niger Delta. Presently, it is a different situation as a result of the changes in the environment caused by pollution. There has been a movement of the indigenes to other communities in the hope of earning a living. Opukri and Ibaba (2008) described this as displacement where he tried to explain the connection between the pollution caused by the operations of the oil MNCs and the displacement of people in the Niger Delta area. He further stated that this process has reduced the economic and developmental aspect of the area without providing better alternatives or options.

Poverty is the main cause of the movement, Opukri and Ibaba (2008) mentioned the concept of internally displaced people (IDP). They cited the United Nation (UN) in explaining the IDP as the involuntary movement of people from their homes within the national borders as a result of natural and human circumstances. Aluko (2004) also mentioned that the Niger Delta is in a poor state due to neglect and the government and oil MNCs have not helped matters with their attitude. He added that due to the government's neglect, the oil MNCs took advantage of the indigenes without any formal agreements, making them victims of the situation. In many cases, they are helpless and cannot fight the companies or the country, even with the living conditions worsening. Aluko (2004) in his survey findings show that most of the indigenes felt that the discovery and production of oil and the resultant destruction of the environment is the major cause of poverty in their land.

Osungade (2011) stated that as a result of the oil wealth, many communities are now fighting amongst themselves causing an increase in the rate of criminal activities. The many communities that exist are constantly in competition for the little resources available and the benefits they get from them. She rightly pointed out that though the MNCs employed qualified indigenous personnel to their labor force, the majority of the Niger Delta population still lives in abject poverty. Similarly, Malina (2010) posited that although this region sits on huge wealth and resources, years of disregard by the host government, increase in corruption and pollution caused by the MNCs operations, the population has felt marginalized and have resorted to raising armed militants to fight their causes. He added that though these groups may not always be fighting for justice for the communities, they sustain themselves through criminal activities such as bunkering, piracy and many more vices.

The table below shows the analysis of oil spills in Nigeria from 1976 - 1996. It shows that over the years the number of spills has increased due to several reasons. It also shows that despite the recovery attempts, not all oil spilled is recovered, leaving some quantities behind in the environment. Though the most common or talked about form of pollution in the Niger Delta is through oil spills in the environment, another form is through gas flaring. Raji and Abejide (2013) stated that continuous flaring of gas has also affected the environment. They added that this region is the second largest flare site globally, burning about 150 million cubic meters yearly, equal to about $25 \%$ and $30 \%$ of gas consumed by the United States and European Union respectively. The author hoped that at the end of this paper, by answering these questions, the stakeholders will become more proactive in their actions in preventing more pollution from occurring and improving the of the people lives who have been adversely affected by their actions as this would improve their perceptions towards them. 
Figure 4: Analysis of Oil Spills

\begin{tabular}{|r|r|r|r|r|}
\hline Year & No. of Spill & $\begin{array}{c}\text { Quantity Spilled(in } \\
\text { barrels) }\end{array}$ & $\begin{array}{c}\text { Quantity Recovered } \\
\text { (in barrels) }\end{array}$ & \multicolumn{1}{c|}{$\begin{array}{c}\text { Quantity Loss to the } \\
\text { Environment(in barrels) }\end{array}$} \\
\hline 1976 & 128 & 26157 & 7135 & 19021.5 \\
\hline 1977 & 104 & 32879.25 & 1703.01 & 31176.75 \\
\hline 1978 & 154 & 489294.75 & 391445 & 97849.75 \\
\hline 1979 & 157 & 94117.13 & 63481.2 & 630635.93 \\
\hline 1980 & 241 & 600.511 .02 & 42416.83 & 558094.2 \\
\hline 1981 & 238 & 42722.5 & 5470.2 & 37252.3 \\
\hline 1982 & 257 & 42841 & 2171.4 & 40669.6 \\
\hline 1983 & 173 & 48351.3 & 6355.9 & 41995.4 \\
\hline 1984 & 151 & 40209 & 1644.8 & 38564.2 \\
\hline 1985 & 187 & 11876 & 1719.3 & 10157.3 \\
\hline 1986 & 155 & 12905 & 522 & 12358 \\
\hline 1987 & 129 & 31866 & 25757 & 25757 \\
\hline 1988 & 208 & 9172 & 1955 & 7207 \\
\hline 1989 & 228 & 5956 & 2153 & 3803 \\
\hline 1990 & 166 & 14150.35 & 2785.96 & 12057.8 \\
\hline 1991 & 258 & 108367.01 & 2785.96 & 49711.2 \\
\hline 1992 & 378 & 51187.9 & 1476.7 & 6632.11 \\
\hline 1993 & 453 & 8105.32 & 2937.08 & 32787.78 \\
\hline 1994 & 495 & 35123.71 & 2335.93 & 60568.15 \\
\hline 1995 & 417 & 63677.17 & 3110.02 & 38716.87 \\
\hline 1996 & 158 & 39903667 & 1183807 & $\mathbf{1 8 2 0 4 1 0 . 5}$ \\
\hline Total & 4647 & $\mathbf{2 3 6 9 4 7 0}$ & $\mathbf{5 4 9 0 6 0 . 3 8}$ & \\
\hline Source: Uyigue and Agho, 2007 & & & \\
\hline
\end{tabular}

It is important to fully understand what CSR means and its importance in a present-day business environment. Bonner and Friedman (n.d) explained that CSR is the ownership of the impact an individual or companies may have had in the society or global environment. They added that it has become a vital part of the business. Though the CSR seems to be a new initiative to be followed, there seemed to be local laws that embraced the fact that businesses should give back to the society (Idemudia, 2007) and this varied for various places. He added that it has as a result of businesses failing to do so that has caused tensions and hostility between companies and local communities. European Commission (2001) as cited by Evuleocha (2005) defined CSR as 'being socially responsible means not only fulfilling legal expectations but also going beyond compliance and investing more into human capital, the environment and relations with stakeholders'.

Idemudia (2007) noted that MNCs in the Niger Delta have not been proponents of CSR initiatives that meet host community's needs; rather it has been the international communities that have pressurized them to focus less on profitability and more on meeting their needs. It is this issue that has caused disputes that have increased the state of unrest and violence in the region, ultimately causing loss of income, life and even more damage to the environment. Idemudia (2007) tried to understand the reason why violent and distrust prevails despite the attempts of these MNCs at improving the CSR image. He saw that it was because of the perceptions of the community over time that experienced years of suffering and damage to their environment and livelihood. This has made it difficult to trust the MNCs.

Idemudia (2007) rightly noted that in trying to measure the impact of the MNCs CSR, the perception of community or individuals being questioned matters a lot. There will be some that believe that the benefits are more than losses and vice versa. He noted a few factors which include needs which have not been met, broken promises and poor communication. Idemudia and Ite (2006) noted that CSR and CCR initiatives by MNCs have not improved relations between host communities and them. They posited that for these schemes to be successful the community's sensitivities and views have to be considered; otherwise, they will not feel involved. It is not just a matter of starting these initiatives but ensuring that they are sustainable and maintained. Davis (1960) as cited by Idemudia and Ite (2006) explained that the point for these companies is not if they can embrace the CSR principle but the degree at which it guides their decisions and operations. Initially, these MNCs were reluctant to go into these operations as they felt it was the government's responsibility, however, they are trying to improve on their investment in the community by implementing social infrastructures.

Although the CSR mostly seems positive, Idemudia and Ite (2006) posited that this has made host communities and even government dependent on these companies for their needs. In conclusion, in order to gain the trust of the community, they stated that the company has to engage them and show them they are trying to meet their expectations and this can be helped by including them at all stages, inception, design, planning, and implementation. CSR should involve all parties and stakeholders so that no stakeholders needs are left unattended. However, managing stakeholders' expectations is not an easy task. Kakabadse, Rozuel, and Lee-Davies (2005) noted that trying to use the stakeholders' approach may be ethical but difficult to manage. 
Wood (1991) as cited by Kakabadse, Rozuel,and Lee-Davies (2005) noted that the challenge maybe because what they understand CSR to be, their expectations, priorities are different, making it difficult to satisfy all of them. In line with portraying sustainable CSR initiatives to improve the livelihood of those impacted, Idemudia (2009) noted that these initiatives are now at the forefront of MNCs business strategies. He added that CSR is now being regarded as not just ways to mitigate the negative effects of the operations of the company but also as a means of improving the areas involved. Unfortunately, in many of these areas, the Nigerian government has been unable to meet the basic needs of its people making them depend more on the MNCs for these issues. Eweje (2007) mentioned that communities such as the Ogoni's have often complained that not enough social and economic infrastructures were visible in their communities.

Maignan et al (2005) as cited by Eweje (2007) noted that by engaging all stakeholders in carrying out sustainable development strategies would be beneficial for companies. This would keep the communities satisfied, improve their environment, reduce poverty levels and crime rates as well as sabotage activities against companies in their locations. Unfortunately, it has also been discovered that many at times, these CSR initiatives are used as 'eye service' to deceive the outside world that the MNCs are actually doing good in areas of operations. Norman and MacDonald (2003) as cited by Akpan (2006) stated that it is often used as a tool to form a good image for the outside world and to try to create a conducive environment which will allow them to work without problems within the communities.

Problems which besiege Niger Delta communities are the fact that many CSR projects are not having the desired effects; rather they are mainly political, meant to calm restive communities (Olawari and Fidelis, 2011). He added that they are mostly top-down initiatives instead of bottom-top initiative where they can correctly meet their needs. Akindele (2011) rightly noted that no matter the business sector, for companies to survive and thrive, they have to earn the approval and trust of the community and this can only be given when they see a beneficial footprint of the companies in their environment. Frynas (2005) in his report noted that there are often many 'white elephant' projects such as clinics and schools which were meant for host communities that were never completed. He stated that a 2001 audit of Shell Corporation showed that less than one-third of its developmental projects were completed. He added that Shell's strategy now is to focus on smaller sustainable long term projects moving away from large infrastructural projects to schemes like micro-credit initiatives. It is the author's intention to investigate if such strategies have changed the perceptions of communities involved.

Tuodolo (2009) noted in his article that companies have been the focus of negative campaigns by individuals, communities and non-governmental organizations despite their activities and contributions to locations in which they are cited. He pondered who had more to gain from the relationship. Previously, many of these MNCs were pushed to take on CSR activities so as to create and maintain a good reputation for themselves; however, they have come to realize its importance in order to remain sustainable. Bird (2004) and Ite (2004) as cited by Tuodolo (2009) stated that CSR activities have had both positive and negative effects to host communities, where most times the negative effects outweigh the positives. Similarly, Ite (2004) pointed out that CSR activities could either build or damage communities socially and economically. He added that in order for these initiatives to succeed, good leadership is important and that by pumping investments into host communities through job creation, improving human capacity and technology transfer, MNCs can impact on them in a positive manner.

Though the Niger Delta is regarded as the 'the goose that lays the golden eggs' its people are poor and over the years, they have maintained peaceful protest but this had taken a turn for the worse and become violent toward the government and oil companies (Akhakpe, 2012). This has had a commercial impact on the economy as companies have had to stop or reduce the quantity of oil being produced. They added that only government cannot handle the issues in the region and suggested that the oil companies help these people through the CSR. Unfortunately, though oil spills and other forms may be difficult to totally eradicate, the companies can mitigate these effects by obeying environmental rules and respecting the rights of the people (Akhakpe, 2012).

Ibaba (2001) as cited by Ebegbulem et al. (2013) noted in his article that apart from the destruction of the environment, the displacement of the indigenous people and the poor compensation meted out to the locals, all as a result of the oil production, it has also caused disputes between communities themselves. Communities now fight amongst themselves to get better benefits from the government and oil companies. Duru (1999) as cited by Ebegbulam et al (2013) posited that even when it seems that the oil companies are providing amenities for the communities; it turns out to be for their own benefit. He gave the example of companies' constructing roads not necessarily for the growth of the community but only to gain access to its facilities. Aworawo (2000) stated that the traditional activities carried out for economic gain has been disturbed by the operations of the oil companies. Azar (1990) as cited by Ebegbulem et al (2013) summarized his research by saying that the operations of these companies in this region have had a multiplier effect on the people, consisting of not only economic and social repercussions but health implications as well. Unfortunately, this is another area which has been neglected. 
There has been an increase in carcinogenic diseases which has been traced to constant exposure of the people in the Niger Delta region to the radioactive elements of gas flaring (Oshwofasa et. al., 2012). He also cited Jike (2004) in stating that community population frequently suffer from respiratory and skin diseases also as a result of gas flaring.

Similarly, Inoni et al. (2006) added that as a result of the pollution caused by the oil MNCs, the once fertile lands of the Niger Delta have become wastelands and infertile making farmers look for alternatives. They added that these effects have been widespread and lasted over a long period because the Nigerian government has failed to maintain strict environmental standards and punish those who have failed to do so. In their research they studied the effects, the pollution had on crop yields and farmers in a few communities. It showed that the amount of food produced reduced drastically because the oil in the soil reduces the amount of air that goes into it as the oil forms a film in the soil which blocks air from entering and it also alters the chemical state of the soil negatively. Iwejingi (2013) noted that the Niger Delta has suffered a great deal since the oil and gas activities started, explaining that from the initial activity of exploration followed by extraction, processing, movement of the product, storage, and usage, each phase creates one type of pollution or another. The Niger Delta region is filled with thousands of kilometers of pipelines, wells and flow stations found near homes, farms and water bodies used by communities (Oshwofasa et al., 2012). They added that most nights, the skies are illuminated by lights from the burning gas in the oil companies facilities known as flares and that these activities have left the region devastated and poverty-stricken.

Though CSR has now become a commonly used term in global business, there does not seem to be an emphasis on actively measuring if these initiatives are effective and of use in the areas they are initiated. Ogula, Rose,and Abii (2010) stated that research has shown that communities in the Niger Delta shape their perception of CSR on the level of poverty being experienced, loss of traditional values and destruction of the local environment. They added that CSR is linked with improving these conditions but that there not a lot of studies investigating and measuring CSR from a human angle in the Niger Delta. The author research intends to shed more light on this issue. The Niger Delta community is an integral stakeholder in the Oil and Gas industry in Nigeria, yet they have been the most negatively affected. Evidence has shown that though the region produces vast resources for the Nigerian nation, they are still largely poverty-stricken. The stakeholder's theory as stated by Argandona (1998) pointed out that a company objective goes beyond just making a profit for its shareholders' but also extends to taking responsibility for its other stakeholders and their interests.

The Nigerian government has had a poor success rate in initiatives to reduce poverty in these areas thereby increasing the pressure of MNCs to carry out these activities (Amadi and Abdullah, 2012). They added that though the MNCs have contributed through CSR, they are still blamed for not doing enough. Elkington, Emerson and Beloe (2006) as cited by Amadi and Abdullah (2012) stated that the search for a win-win situation for all parties, the economy, society, and environment led to the 'triple bottom line' which explains that an organizations success is not only measured by its profits but its social, ethical and environmental practices. Spangler and Pompper (2011) as cited by Musa et al. (2013) noted that organizations that do not incorporate CSR into their activities are prone to negative stakeholder perceptions. They added that without preventive measures against the pollution of the environment, the negative effects of the operations of the Oil and Gas industry is so huge that the value of the CSR is difficult to gauge. It is clear that without a peaceful and conclusive environment, the MNCs cannot operate successfully. Idemudia (2010) noted that frequent kidnapping, blocking of facilities and many more have affected the companies and also impacted government revenue. All these are as a result of a community that is not satisfied.

Aaron (2012) noted that the issue of CSR has had both sides, arguing that one supports keeping the shareholders' interests above cell else while the other promotes ethical and moral behavior. Despite this, he added that presently, global business cannot exist in a vacuum but in a social environment. Frynas (2005) stated that CSR should not only be considered from an international point of view but most importantly from the societal point. He added that it is important to ask if the CSR efforts of the companies are being put to good use and impacting the areas positively. He made another point by saying the sustainable way to improve a community is by empowering them to help themselves rather than initiating activities which will be carried out as experts or expatriates. The importance of having all stakeholders involved in major decisions cannot be overemphasized. When communities are involved from the initial stages, the chances of problems developing along the line reduces. World Bank (1996) as cited by Adomokai and Sheate (2004) noted that communities have important contributions to add to decisions concerning their environment. They added that companies should understand the needs of host communities and gain their support in order to allow their operations to go through without problems. Due to the conditions they find themselves, the youth have taken up arms to fight the companies and government to improve their situations. Ikelegbe (2006) in his article pointed out that youth violence against MNCs increased following several years of environmental pollution, economic exploitation and poor treatment of host communities by MNCs, resulting to their attacking their facilities. 
He added that the MNCs were protected by security agencies and so did not initiate CSR programmes to benefit communities. Similarly, Jike (2004) stated that the agitation and restlessness of the youth are as a consequence of unmet expectations from both parties and so they feel they have to fight back.

\section{Materials and Methods}

\subsection{Feasibility of the study}

The author is fortunate to be in the same industry that she wrote about and has worked in many of the areas affected and seen the effect. She interacted with individuals in communities in the Niger Delta as well as those working in the industry to get their perspective on this issue. Getting information such as the size of the areas affected, the quantity of oil spilled and the effects on health was difficult without carrying out scientific tests, apart from what was visibly seen. These were reasons why the author used both qualitative and quantitative research approaches which allowed her to get some statistics and form her analysis as well as using information from other authors to support her work.

The data was collected through a combination of questions for questionnaires and previously carried out research on similar topics and also health bodies and non-governmental bodies involved in fighting this issue. She researched for historical data showing major spills recorded as well as the frequency of them. There was a lot of difficulty in obtaining data from involved parties due to privacy or confidentiality laws as well as government bureaucracies which could delay or prevent data collection as well. Another problem was that many of the spills were regarded as minor and were not documented or recorded; only those considered as major spills got news coverage and were documented. Vidal (2010) mentioned that little news coverage had been given to many of Nigeria's oil spill as compared to those in other developed countries such as the BP's Deepwater Horizon spill that occurred in the Gulf of Mexico.

\subsection{Methodology}

The author used a combination of qualitative and quantitative research methods. For her research, the author used more of the positivist approach as it allowed her to use the benefits to support her work. Zawawi (2007) explained that through positivism, the world is looked at being external and one that can be measured by objective means rather than subjective means. The survey approach was the chosen method as it involved the analysis of information collected from a large number of research variables. Zawawi (2007) stated that for many researchers, adopting the mixed method would be favorable as the qualitative method allows the author to gain a general understanding of the issue while quantitative methods allow for a deeper understanding and vice versa in some cases. After checking the various methods of collecting information, the stratified random techniques and snowball techniques were best suited for the author's research. This was because the individuals targeted for this research were those who had lived or worked in the in the Niger Delta where activities that had to do with the Oil and gas industry was carried out and also those within the ages of 25 and above, and because they would have experienced the operations and seen the impact of these MNCs in their environment. The author recognized that it was only such individuals that could provide accurate perceptions.

Since the research was based on a particular area in Nigeria, the Niger Delta, the author had to select her participants to contain individuals who come from these areas, have lived in the Niger Delta for long periods and those that have worked in communities affected by actions of the companies. She tried to meet with individuals who remember what their experiences were before the onset of the oil exploration and pollution thereafter. She hoped to gain knowledge from their experiences, perceptions, and expectations.

\section{Results}

\subsection{Qualitative Results}

The researcher interviewed 18 people altogether, 9 in the group made up of her colleagues and the other 9 from the host communities. The researcher used the codes GOC (Group for colleagues) and GOH (Group for host communities). She gathered her information by taking notes and recordings. Everyone in the GOC had knowledge of what CSR meant and its importance but this was not always the case for those in the GOH. Education had some influence on this because the GOC group were educated and exposed to global standards, unlike the GOH group.

There was a noticeable difference between the attitudes of the two groups. In the GOH, many of the respondents felt that although the MNCs had achieved some positive results, they thought much more could be achieved to improve the welfare of the community. This sentiment was a bit muted in the GOC as many of them had gained better education, scholarships, and employment from these MNCs as well and this had improved their lifestyle. It was also easier to interview the GOC group as they were more educated, exposed and understood more about what CSR actually meant making the interview process shorter in duration, unlike the GOH group who did not really understand what it meant but still knew how they had been affected, what they lacked and what they needed. 


\subsection{Quantitative results}

The questionnaire asked participants if they had been negatively affected by the operations of MNCs, results showed that from the 104 participants, $10(9.63 \%)$ strongly disagreed, $5(4.81 \%)$ disagreed, $3(2.88 \%)$ neither disagreed or agreed, $36(34.62 \%)$ agreed and $50(48.08)$ strongly agreed. This correlated with the interviews carried out by the author where most of the participants especially in the GOH group felt that the activities of these companies had negatively affected them. They comprised mostly of the older generations who had known the era before these effects became pronounced. Those that disagreed were the younger generation that had perhaps gained by their presence through education, scholarships, and employment.

The analysis for the question that oil companies do not have good relations with their host communities explained that $13(12.5 \%)$ strongly disagreed, $48(46.15 \%)$ disagreed, $25(24.04 \%)$ were unsure, $17(16.35 \%)$ agreed and $1(0.96 \%)$ strongly agreed. This result cuts across the two groups of participants, many of them felt that though perceptions had changed over time favoring improved relations, they still felt that it could be better amongst both parties.

In investigating if Oil MNCs issued CSR programmes to help host communities, the results showed that $2(1.92 \%)$ strongly disagreed, 4 (3.85\%) disagreed, $16(15.38 \%)$ were undecided, about $70(67.31 \%)$ agreed and $12(11.54 \%)$ strongly agreed. It was the perception of a large percentage of the participants that many of the programmes originated and initiated were for the benefit of the community. Similarly, majority of participants (76) agreed that MNCs had initiated CSR programmes to improve their reputation, 10 (9.62\%) both strongly agreed and were undecided. Also, 4 $(3.85 \%)$ both disagreed and strongly disagreed. More participants believed that they had done so to improve their reputation locally and internationally. This result buttressed the perception of the affected communities that most of the CSR programmes were not necessarily done to improve their plight but to improve the standing of the companies in the global business world.

In answering if the CSR programmes initiated by the MNCs had been effective, most of the participants strongly disagreed, $14(13.46 \%)$ strongly disagreed. 36 (34.62\%) were undecided, $45(43.27 \%)$ agreed and about $9(8.65 \%)$ strongly agreed. The perception the community had of the MNCs depended on if they felt they are part of the decisionmaking process in the initiation, planning, and execution of the programmes set up for their benefit. The survey showed that $2(1.92 \%)$ strongly disagreed, $22(21.15 \%)$ disagreed, 31 (29.81\%) were undecided while $42(40.38 \%)$ agreed. Depending on the community, where they felt they had been part of the process, it made it easier for the oil companies to carry out the CSR programme or project and also carry out their business activities.

In investigating if the relationship between host communities and MNCs had improved since the commencement of CSR initiatives, results showed that $1(0.96 \%)$ strongly disagreed, $11(10.58 \%)$ disagreed, $32(30.77 \%)$ were undecided, $55(52.88 \%)$ agreed and $5(4.81 \%)$ strongly agreed. For all the participants that took part in this exercise, majority of them felt that over time, the relationship had improved between both parties. This could be as a result of several factors, initiation of CSR initiatives, companies being more proactive in reducing pollution, companies setting up departments to handle issues concerning host communities, getting the communities involved in some of their activities and many more.

The author asked if infrastructures such as roads, bridges, and electricity had improved, $4(3.85 \%)$ strongly disagreed, 6 (5.77\%) disagreed, $16(15.38 \%)$ were undecided, 62 (59.62\%) agreed and $16(15.38 \%)$ strongly agreed. By combining the results of those who answered positively, there was a consensus amongst participants that the oil companies have improved the infrastructures in the community.

\section{Conclusions}

The above analysis showed that $54(51.92 \%)$ agreed that the relationship between community and oil MNCs had improved since the commencement of CSR initiatives, $2(1.92 \%)$ strongly disagreed, 11 (10.58\%) disagreed, 32 $(30.77 \%)$ were undecided and $5(4.81 \%)$ strongly agreed. The results confirmed that the initiation of these initiatives has helped to placate and smoothen over the relationship of both parties. There was a general feeling that MNCs who did not perform CSR initiatives in the area they carry out their operation should be sanctioned globally by the global business world. $69 \%$ of the participants agreed with this sentiment.

\subsection{Recommendation}

At the completion of the research, the author has recommendations for the following bodies:

\section{Government}

1) The governmentshould ensure that these companies initiate sustainable CSR programmes in host communities where they operate, partnering with qualified indigenous companies so as to transfer knowledge and expertise, 
thereby improving their competence. To further ensure this, there should be fines and in serious violations, penalties in place for MNCs that do not follow government policies.

2) The establishment of regional spill response teams along Nigeria's coastline would help in managing oil spill issues (Smith and Loza, 1994 as cited by Nwilo and Badejo, 2008). Since they are near the affected zone, it would enable act faster, receiving information earlier and reaching the site quicker.

3) They should look into the appropriation and distribution of CSR initiatives proposed by MNCs and communities to ensure that they are carried out in places that need them most. In many cases, the locations of proposed infrastructures to be constructed are chosen by a few members of the community to favor their own interests.

4) With so much focus on the environment and environmentally friendly policies, the government should encourage these MNCs to adopt environmentally friendly methods in their operations and ask oil companies to produce an EIA for all their activities comprising of installation of pipeline, flares, and other equipment.

5) The government should ensure that compensations are paid to affected communities to enable them to bear their losses.

6) They should insist on Memorandum of Understanding (MOU) for companies operating in this region with all host communities. These are documents are not legally binding but signify agreements between parties for a particular line of action to be carried out.

7) As stated by Ering et al. (2013), the government should increase the budgetary allocation for security in this area to safeguard oil facilities, discourage militant activities and guard them against sabotage by communities which eventually also affects them.

\section{$\underline{\text { Regulatory Bodies }}$}

1. National and international Regulatory bodies should monitor even more closely the oil MNCs activities to ensure strict adherence to global and national standards. This would keep them in check as they would want to maintain their reputations in the global business world.

2. They should ensure that all oil spills are quickly noted, recorded and cleaned up. They should also guarantee that these companies maintain their equipment and facilities regularly to prevent spills from them. Other issues such as reducing or eliminating completely gas flaring are also important to reduce the amount of air pollution.

\section{Oil companies}

1. Since these oil companies are mostly international companies, it would be a good strategy for these companies to make efforts in bridging the cultural gap between many of its employees and their standards compared to the host community. This can be helped by employing indigenes who would act as the middlemen between the company and the host communities.

2. Oil companies should involve communities at an early stage in the planning of CSR programmes meant for them. Their opinions would guide the companies in putting up the right infrastructure that would benefit them best.

3. They should partner or mentor small and indigenous companies so as to improve the competence and confidence in carrying out more technical activities. Presently, oil companies want to have a good reputation and be regarded as corporate citizens and so working with indigenous partners would project a good image.

4. Implementing clean-up activities as part of their CSR activities to restore the environment to a clean state. This involves a quick response to spills and eliminating gas flaring in their operations.

5. The author cites Iwejingi (2013) in suggesting that an increase in the rates given to communities as compensation would help ease the conditions of the affected areas.

\section{Communities}

1. The communities should teach their people that sabotaging the equipment of the oil companies harms them also (Bayode et al., 2011), increasing the rate of pollution in their environment.

2. Community indigenes should develop themselves through education and desist from criminal activities and in turn, help themselves and their communities.

3. The author suggested that they should make the effort to retrain themselves in other skills to improve their livelihood since their traditional professions had been affected by polluted environment.

Results from participants showed that though their perception of the oil MNCs had improved over time, they feel that a lot must be done by these companies in proportion to what they are gaining from them. The results also showed a disparity between both groups involved in this survey. The author's colleagues who are from these communities affected but were gainfully employed have a better perception of the MNCs as they have benefitted from them through education, scholarship, and employment which have made a positive impact on them. 
In the other case, the second group made up of indigenous community members, they have a more negative view of the companies as they felt they have not gained individually. Idemudia and Ite (2006) stated that though some initiatives had been carried out, they are not fully appreciated by the community as they felt they were not carried along in the actualization of the process. Results of the survey showed that in recent times, this perception had changed. Though there may still be protests and disagreements between both parties, this had reduced as MNCs have found more ways to be interactive in partnering with host communities. Kakadse, Rozuel,and Lee-Davies (2005) rightly noted that managing different stakeholders would prove to be difficult but in this case, prioritizing their needs and expectations even amongst the various communities and coming to a compromise would be the best strategy.

\section{References}

Aaron, K. (2012). New corporate social responsibility models for oil companies in Nigeria's delta region: What challenges for sustainability? Progress in Development Studies, 12(4), 259-273. doi: $10.1177 / 146499341201200401$

Adomokai, R., \& Sheate, W. (2004). Community participation and environmental decision-making in the Niger Delta. Environmental Impact Assessment Review, 24(5), 495-518. doi: 10.1016/j.eiar.2004.01.002

Akhakpe, I. (2012). Oil-environmental degradation and human security in the Niger-Delta region of Nigeria: Challenges and possibilities. European Scientific Journal, ESJ, 8(26).

Akindele, R. (2011). Corporate social responsibility: An organizational tool for survival in Nigeria. IFE Psychologia, 19(2), 114-126. doi: 10.4314/ifep.v19i2.69516

Akpan, W. (2006). Between responsibility and rhetoric: Some consequences of CSR practice in Nigeria's oil province. Development Southern Africa, 23(2), 223-240. doi: 10.1080/03768350600707488

Aluko, M. (2004). Sustainable development, environmental degradation and the entrenchment of poverty in the Niger Delta of Nigeria. Journal of Human Ecology, 15(1), 63-68. doi: 10.1080/09709274.2004.11905668

Amadi, B., \& Abdullah, H. (2012). Poverty alleviation through corporate social responsibility in Niger Delta, Nigeria. Asian Social Science, 8(4), 57. doi: 10.5539/ass.v8n4p57

Argandoña, A. (1998). The stakeholder theory and the common good. Journal of Business Ethics, 17(9-10), 1093-1102.

Aworawo, D. (2013). Deprivation and resistance: Environmental crisis, political action, and conflict resolution in the Niger Delta since the 1980s. Journal of International \& Global Studies.

Bayode, O.J.A., Adewunmi E.A., \& Odunwole, S (2011). Environmental implications of oil exploration and exploitation in the coastal region of Ondo State, Nigeria: A regional planning appraisal. Journal of Geography and Regional Planning, 4(3), 110-121.

Bonner, J., \& Friedman, A. (2016). Corporate social responsibility: Who's responsible? Finding an organizational home for an increasingly critical function.

Egbe, R. E., \& Thompson, D. (2010). Environmental challenges of oil spillage for families in oil producing communities of the Niger Delta Region. Journal of Home Economics Research, 13, 24-34.

Ebegbulem, J., Ekpe, D., \& Adejumo, T. O. (2013). Oil exploration and poverty in the Niger Delta region of Nigeria: A critical analysis. International Journal of Business and Social Science, 4(3), 279-287.

Erıng, S., Bassey, G., \& Odike, E. (2013). The Niger Delta crisis in Nigeria: Pre and post amnesty situation. Mediterranean Journal of Social Sciences, 4(6), 421-427. doi: 10.5901/mjss.2013.v4n6p421

Evuleocha, S. U. (2005). Managing indigenous relations: Corporate social responsibility and corporate communication in a new age of activism. Corporate Communications: An International Journal, 10(4), 328-340.

Eweje, G. (2007). Multinational oil companies' CSR initiatives in Nigeria: The scepticism of stakeholders in host communities. Managerial Law, 49(5/6), 218-235.

Frynas, J. G. (2005). The false developmental promise of corporate social responsibility: Evidence from multinational oil companies. International affairs, 81(3), 581-598.

Idemudia, U. (2009). Oil extraction and poverty reduction in the Niger Delta: A critical examination of partnership initiatives. Journal of Business Ethics, 90(1), 91-116.

Idemudia, U., \& Ite, U. E. (2006). Corporate-community relations in Nigeria's oil industry: Challenges and imperatives. Corporate Social Responsibility and environmental management, 13(4), 194-206.

Idemudia, U. (2009). Oil extraction and poverty reduction in the Niger Delta: A critical examination of partnership initiatives. Journal of Business Ethics, 90(1), 91-116.

Idemudia, U. (2010). Rethinking the role of corporate social responsibility in the Nigerian oil conflict: The limits of CSR. Journal of International Development, 22(7), 833-845.

Ikelegbe, A. (2006). The economy of conflict in the oil rich Niger Delta Region of Nigeria. African and Asian Studies, 5(1), 23-56. doi: 10.1163/156920906775768291 
Ite, U.E (2004). Multinationals and corporate social responsibility in developing countries: A case study of Nigeria. Corporate Social Responsibility and Environmental Management, 11(1), 1-11.

Iwejingi, S. F. (2013). Socio-economic problems of oil exploration and exploitation in Nigeria's Niger Delta. Journal of Energy Technologies and Policy, 3(1), 76-80.

Jike, V. T. (2004). Environmental degradation, social disequilibrium, and the dilemma of sustainable development in the Niger-Delta of Nigeria. Journal of Black Studies, 34(5), 686-701.

Kakabadse, N. K., Rozuel, C., \& Lee-Davies, L. (2005). Corporate social responsibility and stakeholder approach: A conceptual review. International Journal of Business Governance and Ethics, 1(4), 277-302.

Malina, T. (2010). Niger Delta. Retrieved from http://research.ridgway.pitt.edu/blog/2010/03/15/niger-delta/

Musa, A., Yusuf, Y., McArdle, L., \& Banjoko, G. (2013). Corporate social responsibility in Nigeria's oil and gas industry: The perspective of the industry. International Journal of Process Management and Benchmarking, 3(2), 101. doi: 10.1504/ijpmb.2013.057722

Ndpifoundation.org (2014). Innovative partnerships for sustainable livelihoods in the Niger Delta region. (2014). Retrieved from http://ndpifoundation.org/

Nwilo, P. C., \& Badejo, O. T. (2006). Impacts and management of oil spill pollution along the Nigerian coastal areas. Administering Marine Spaces: International Issues, 119, 1-15.

Nwilo, P. C., \& Badejo, O.T (2008). Impacts of oil spills along the Nigerian coast. Soil, Sediment \& Water. Retrieved from http://web.archive.org/web/20080430164524/http://www.aehsmag.com/issues/2001/october/impacts.htm\#top

Odoemene, A. (2014). Social consequences of environmental change in the Niger Delta of Nigeria. Journal of Sustainable Development, 4(2), 123-135. doi: 10.5539/jsd.v4n2p123

Inoni, O., Omotor, D. and Adun, F. (2006). The effect of oil spillage on crop yield and farm income in Delta State, Nigeria. Journal of Central European Agriculture, 7(1), 41-48.

Ogula, D., Rose, J., \& Abii, F. (2012). A phenomenological study of corporate social responsibility in the Niger Delta, Nigeria. Journal of Leadership Studies, 6(2), 32-47. doi: 10.1002/jls.21236

Olawari, D. J., \& Fidelis, A. E. (2011). The rhetoric of corporate social responsibility (CSR) in the Niger Delta. American International Journal of Contemporary Research, 1 (3).

Opukri, C. O., \& Ibaba, I. S. (2008). Oil induced environmental degradation and internal population displacement in the Nigeria's Niger Delta. Journal of Sustainable Development in Africa, 10(1), 173-193.

Oshwofasa, B. O., Anuta, D. E., \& Aiyedogbon, J. O. (2012). Environmental degredation and oil industry activities in the Niger-Delta region. African Journal of Scientific Research, 9(1).

Osungade, E. (2011). Nigerian history of Niger Delta crisis. Retrieved from Forgottendairies. org.

Raji, A. O. Y., \& Abejide, T. S. (2013). An assessment of environmental problems associated with oil pollution and gas flaring in the Niger Delta Region Nigeria, C. 1960s-2000. Arabian Journal of Business and Management Review (Oman Chapter), 3(3), 48.

Stakeholder Democracy Network (2014) - Introduction to Nigeria. Retrieved from http://www.stakeholderdemocracy.org/

Tuodolo, F. (2009). Corporate social responsibility: Between civil society and the oil industry in the developing world. ACME: An International E-Journal for Critical Geographies, 8(3), 530-541.

Vidal, J. (2010). Nigeria's agony dwarfs the Gulf oil spill. The US and Europe ignore it. The Guardian.

Zawawi, D. (2007). Quantitative versus qualitative methods in social sciences: Bridging the gap. Integration \& Dissemination, 1, 3-4. 